\title{
Fluconazole and voriconazole susceptibility in oral colonization isolates of Candida spp. in HIV patients.
}

\author{
Daniela Brito ${ }^{1}$, Johelia Fernándes ${ }^{1}$, María Andrea Castillo ${ }^{1}$, Sandra Azuero ${ }^{1}$, \\ Rosaura Hernández-Valles², Yotsabeth Saúl-García², Nereida Valero ${ }^{3}$, \\ Rafael Villalobos ${ }^{4}$, Neomar Semprún-Hernándes ${ }^{1}$ and Dilia Martínez-Méndes ${ }^{1,5}$ \\ ${ }^{1}$ Immunology Lab. Facultad Experimental de Ciencias. Universidad del Zulia. Maracaibo, \\ Venezuela. \\ ${ }^{2}$ Micology Lab. Medical School. Universidad Nacional "Franciseo de Miranda" (UNEFM). \\ Coro, Venezuela. \\ ${ }^{3}$ Instituto de Investigaciones Clínicas "Dr. Américo Negrette”. Universidad del Zulia. \\ Maracaibo, Venezuela. \\ ${ }^{4}$ HIV\&AIDS Program. Servicio Autónomo Hospital Universitario de Maracaibo \\ (SAHUM). Maracaibo, Venezuela. \\ ${ }^{5}$ GP Supervisor.International SOS. Malongo, Angola.
}

Key words: candidiasis; HIV; antifungal susceptibility; non-albicans species.

\begin{abstract}
The identification of Candida species and their antifungal susceptibility is important for the treatment of infected patients. The aim was to determine the susceptibility to fluconazole and voriconazole in isolates from oral colonization of Candida spp. in HIV patients. From the 135 patients studied, 33.3\% were females and $66.7 \%$ males, with a mean age of 36.6 years and $83.7 \%$ of them were under treatment. The identification of the specie was performed by the API20CAUX ${ }^{\circledast}$ test and the antifungal susceptibility was determined by the dise diffusion test. Strains of C. parapsilosis and C. krusei were used as quality controls. The Candida species identificated were: C. parapsilosis complex 52\%, C. albicans complex 36\% and C. famata 12\%. 60\% of the isolates were susceptible to fluconazole and $40 \%$ were dose-dependent. All were susceptible to voriconazole. In this study, none of the patients had oropharyngeal candidiasis however, $18.5 \%$ had Candida spp. colonization, this percentage being below other studies in HIV carriers. We found a high proportion of nonalbicans species but no difference in the CD4+ counts between patients.
\end{abstract}

Corresponding author: Dilia Martínez-Méndez . GP Supervisor.International SOS. Malongoo, Angola. Email: dkmartinez.mw@gmail.com 


\section{Susceptibilidad a fluconazol y voriconazol en aislados orales de Candida spp. en pacientes con viH.}

Invest Clin 2019; 60 (4): 275-282

Palabras clave: candidiasis; VIH; susceptibilidad antifúngica; especies no-albicans.

Resumen. Identificar las especies de Candida y la susceptibilidad a los antifúngicos es importante para el tratamiento adecuado de pacientes infectados. El objetivo fue determinar la susceptibilidad a fluconazol y voriconazol de Candida spp. en aislados de colonizaciones orales en pacientes con VIH. La identificación se realizó mediante la prueba API20CAUX ${ }^{\circledR}$ y la prueba de difusión de disco para la sensibilidad a los antifúnǵicos. Se utilizaron cepas de C. parapsilosis y C. krusei como control de calidad. De los 135 pacientes, el 33,3\% eran mujeres y el 66,7\% hombres con una edad media de 36,6 años y el $83,7 \%$ recibían tratamiento. Las especies de Candida identificadas fueron: complejo C. parapsilosis 52\%, complejo C. albicans 36\% y C. famata 12\%. La susceptibilidad al fluconazol 60\% eran susceptibles y 40\% dependía de la dosis. Todas eran susceptibles al voriconazol. En este estudio, ninguno tenía candidiasis orofaríngea, sin embargo, el 18.5\% tenía colonización por Candida spp., aunque el porcentaje está por debajo de otros estudios en portadores de VIH. Encontramos una alta proporción de especies no-albicans. No hubo diferencias en el recuento de $\mathrm{CD} 4^{+}$entre los pacientes.

Received: 05-11-2018 Accepted:09-10-2109

\section{INTRODUCTION}

In HIV patients under antiretroviral therapy (ART) a reduction of oral candidiasis by $C$. albicans have been observed; however, the emergence of non-albicans species with resistance to antifungal agents has also been observed and the presence of oral Candida spp. in these patients can predict the development of oral candidiasis (1-3). To identify the Candida species involved and the study of antifungal susceptibility is important for the epidemiological mapping of the species and to improve the treatment of these patients(4). Fluconazole is used in the treatment of HIV/AIDS associated opportunistic yeast infections and prolonged exposure is associated with the increase of resistance $(1,4,5)$. The aim of this work was to determine the susceptibility to fluconazole (FCZ) and voriconazole (VCZ) in the isolates of the oral colonization of Candida spp. in HIV/AIDS patients.

\section{METHODS}

A cross-sectional study was made in 135 seropositive HIV patients previously diagnosed by ELISA and confirmed by Western blot at the University Hospital (SAHUM) HIV/AIDS program, Maracaibo - Venezuela. None had clinical evidence of oral candidiasis. Patient's age, CD4 ${ }^{+}$T-lymphocyte count, World Health Organization (WHO) immunological classification for established HIV infection (5) and ART were obtained from their medical records. 
Ethical clearance was obtained by the Medical board in accordance with the ethics committee of SAHUM and participants signed informed consent. Identification and susceptibility were reported to each subject and the attending physician.

Samples: A swab was collected from the oral mucosa, floor of the mouth and dorsal tongue. Samples were cultured in Sabouraud-dextrose agar (SDA - BD Difeo ${ }^{\mathrm{TM}} \mathrm{MD}$, USA) with ampicillin $(500 \mathrm{mg} / \mathrm{L})$ for $24 \mathrm{~h}$ at $35^{\circ} \mathrm{C}$. Blastoconidies were observed.

Identification: Pure colonies were plated in CHROMAgar ${ }^{\circledR}$ Candida (Biomedics ${ }^{\circledR}$ ) for $48 \mathrm{~h}$ at $35^{\circ} \mathrm{C}$ following manufacturer's instructions. Morphology and color on CHROMAgar $^{\circledR}$ Candida colonies were noted. Germ tube test was achieved inoculating $0.5 \mathrm{ml}$ of sheep sterile serum with a scoop $(5 \mu \mathrm{l})$ of yeast, incubated for $3 \mathrm{~h}$ at $37^{\circ} \mathrm{C}$. Isolates with germ tube-positive were presumed to be C. albicans complex. Chlamydospores production was assessed by culturing on cornmeal agar supplemented with $1 \%$ Tween-80 (SIGMA-ALDRICH $\left.{ }^{\circledR}\right)$ at $25^{\circ} \mathrm{C}$ for $72 \mathrm{~h}$ followed by microscopic observation. The isolates were identified by API20CAUX ${ }^{\circledR}$ test (bioMérieux ${ }^{\circledR} \mathrm{SA}$, Marcy-l'Etoile, France) in accordance with manufacturer's instructions.

Antifungal susceptibility of identified isolates as outlined in NCGLS M44-A2 document for disc diffusion susceptibility testing in yeasts using Mueller Hinton $+2 \%$ glucose $+0.5 \mathrm{~g} / \mathrm{mL}$ methylene blue dye (GMB) agar and FCZ $(25 \mu \mathrm{g})$ and VCZ dises (1 $\mu \mathrm{g})$ (Bioanalyse $\left.{ }^{\circledR}\right)$. After $24 \mathrm{~h}$ at $37^{\circ} \mathrm{C}$ of incubation, the zones of inhibition were measured. FCZ breakpoint for C. albicans, C. parapsilosis and C. tropicalis was: sensible (S) $\geq 17$; dose-dependent sensibility (DDS) 14-16 and resistance $(\mathrm{R}) \leq 13$. For C. glabrata $(\mathrm{S}) \geq 17$; $\mathrm{SDD} \geq 15$ y $\mathrm{R} \leq 14$. VCZ breakpoint was $\mathrm{S}$ $\geq 17$; DDS $15-16$ and $\mathrm{R} \leq 14$ to C. albicans, C. parapsilosis, C. tropicalis and $\mathrm{S} \geq 15$; DDS 13-14; $\mathrm{R} \leq 12$ to C. krusei $(6,7)$. Minimal inhibitory concentration (CMI) results were interpreted according to CLSI interpre- tive criteria $(6,7)$. As quality control, ATCG strains of C. parapsilosis 22019 and C. krusei 6258 were used. For statistical analysis, the chi-square test and the Fisher's exact test using the Graph Pad Prism 5.0 program were used.

\section{RESULTS}

A total of 135 patients with a confirmed diagnosis of HIV were enrolled on this study, 33.3\% $(\mathrm{n}=45)$ females and $66.7 \%(n=90)$ males with a mean age of 36.6 years $(\mathrm{SD} \pm 11.28)$ rangiing from 21 to 60 years $(p=0.21)$. According to WHO (5) immunological classification for established HIV infection $\left(\mathrm{mm}^{3} / \mathrm{CD}^{+}\right): 27.4 \%$ $(n=37)$ of the patients had not significant, immunosuppression; 22.2\% $(\mathrm{n}=30)$ mild; $16.3 \%(n=22)$ advanced and $17.8 \%(n=24)$ severe with less than $200 \mathrm{cel} / \mathrm{mm}^{3}$. $16.3 \%$ $(n=22)$ had no information on the medical chart because they are new incomings patients to the HIV program at the day that sample was collected $(p=0.48) .83 .71 \%$ $(n=113)$ patients were on ART and $16.9 \%$ $(n=22)$ were not because they were the new incoming patients $(p=0.96)$. The most frequent treatment regimen was the combination with nucleoside reverse transeriptase inhibitor (NRTI) plus a protease inhibitor (PI) followed by a non-nucleoside transeriptase inhibitor (NNRTI) and a nucleotide reverse transcriptase inhibitor (NtRTI) or PI. Only one patient used a fusion inhibitor (FI) and none used integrase inhibitor (II) $(p=0.96)$. Of all 135 patients $67.4 \%$ $(\mathrm{n}=91)$ were not under antimicrobial therapy, but $11.9 \%(n=16)$ reported use of any antifungal (fluconazole, ketoconazole or amphotericin B), 20\% $(n=27)$ antibacterial (cotrimoxazole, amoxicillin, azithromycin or clarithromycin) and less than $1 \%(n=1)$ antiparasitic (metronidazole) $(p=0.60)$. Non-statistical significance was observed between age, gender, CD $4+$ and use of the ART or antimicrobial $(p>0.05)$ (Table I). 
TABLE I

GENDER, CD4 ${ }^{+}$CEL/ $/ \mathrm{MM}^{3}$, TREATMENT AND Candida spp. CULTURE

\begin{tabular}{|c|c|c|c|c|c|c|}
\hline \multirow[t]{2}{*}{ Characteristics } & \multicolumn{2}{|c|}{$\begin{array}{l}\text { Positive } \\
\text { Candida spp. } \\
(\mathrm{n}=25)\end{array}$} & \multicolumn{2}{|c|}{$\begin{array}{l}\text { Negative } \\
\text { Candida spp. } \\
(\mathrm{n}=110)\end{array}$} & \multicolumn{2}{|c|}{ Total } \\
\hline & $\mathrm{Fx}$ & $\%$ & $\mathrm{Fx}$ & $\%$ & $\mathrm{Fx}$ & $\%$ \\
\hline Age, mean \pm SD (years) & \multicolumn{2}{|c|}{$39.92 \pm 10.85$} & \multicolumn{2}{|c|}{$35.83 \pm 11.34$} & \multicolumn{2}{|c|}{$36.6 \pm 11.28$} \\
\hline Gender & & & & & & $p=0.21$ \\
\hline Female & 11 & 8.14 & 34 & 25.18 & 45 & 33.33 \\
\hline Male & 14 & 10.37 & 76 & 56.29 & 90 & 66.66 \\
\hline $\mathrm{CD} 4+\mathrm{cel} / \mathrm{mm}^{3}$ (WHO Classification) & & & & & & $p=0.48$ \\
\hline$>500$ Not signnificant & 8 & 5.92 & 29 & 21.48 & 37 & 27.40 \\
\hline 350-499 Mild & 8 & 5.92 & 22 & 16.29 & 30 & 22.22 \\
\hline 200-349 Advanced & 2 & 1.48 & 20 & 14.81 & 22 & 16.29 \\
\hline$<200$ Severe & 3 & 2.22 & 21 & 15.55 & 24 & 17.77 \\
\hline Not Information* & 4 & 2.96 & 18 & 13.33 & 22 & 16.29 \\
\hline Antiretroviral therapy (ART) & & & & & & $p=0.96$ \\
\hline 1-4 Druǵs & 21 & 15.55 & 92 & 68.14 & 113 & 83.71 \\
\hline New patient No ART & 4 & 2.96 & 18 & 13.33 & 22 & 16.29 \\
\hline Antimicrobial Therapy & & & & & & $p=0.60$ \\
\hline Antifungal & 2 & 1.48 & 14 & 10.37 & 16 & 11.85 \\
\hline Antibacterial & 6 & 4.44 & 21 & 15.55 & 27 & 20.00 \\
\hline Antiparasitic & 0 & 0.00 & 1 & 0.74 & 1 & 0.74 \\
\hline No Antimicrobial therapy & 17 & 12.59 & 74 & 54.81 & 91 & 67.4 \\
\hline
\end{tabular}

"New patients without information in the medical chart at the sample collection day.

All 135 patients had no clinical evidence of oral candidiasis (angular cheilitis, leukoplakia or oral ulcerations), however, $18.5 \%(\mathrm{n}=25)$ were colonized by Candida spp. Of these, $52 \%(n=13)$ were identified as C. parapsilosis complex (C. parapsilosis sensu stricto, C. orthopsilosis and $C$. metapsilosis); 36\% ( $\mathrm{n}=9)$ C. albicans complex (C. dubliniensis, C. stellatoidea and $C$. africana) and $12 \%(\mathrm{n}=3)$ C. famata. The fluconazole MIC at 48 hours showed that $60 \%(n=15 / 25)$ were susceptible, of these, $24 \%(n=6 / 25)$ C. parapsilosis complex, $24 \%(n=6 / 25)$ C. albicans complex and $12 \%$ $(n=3 / 25)$ C. famata and 40\% $(n=10 / 25)$ had doses dependent susceptibility, 28\% $(\mathrm{n}=7 / 25)$ C. parapsilosis complex and $12 \%$ $(\mathrm{n}=3 / 25)$ C. albicans complex. None were resistant $(p=0.75)$. All species of Candida identificated were susceptible to voriconazole MIC $(p=0.43)$. Four patients with Candida spp. colonization were new incomings patients to the HIV/AIDS program without ART. One of these was admitted to the hospital with complicate tuberculosis plus oral $C$. parapsilosis and other with a neurocryptococosis plus oral C. famata. Also, two of the seven C. parapsilosis with doses dependent susceptibility was using FCZ daily for more than a month $(p=0.47)$. Non-statistical significance was observed $(p>0.05)$ (Table II). 
TABLE II

CANDIDA SPECIES IDENTIFICATION BY GENDER, ANTIFUNGAL SUSCEPTIBILITY, $\mathrm{CD} 4{ }^{+} \mathrm{CEL} / \mathrm{MM}^{3}$ AND TREATMENT.

\begin{tabular}{|c|c|c|c|c|c|c|c|c|}
\hline \multirow[t]{2}{*}{ Characteristic } & \multicolumn{2}{|c|}{$\begin{array}{l}\text { C. parapsilosis } \\
(\mathrm{n}=13)\end{array}$} & \multicolumn{2}{|c|}{$\begin{array}{l}\text { C. albicans } \\
(\mathrm{n}=9)\end{array}$} & \multicolumn{2}{|c|}{$\begin{array}{l}\text { C. famata } \\
(\mathrm{n}=3)\end{array}$} & \multicolumn{2}{|c|}{ Total } \\
\hline & $\mathrm{Fx}$ & $\%$ & $\mathrm{Fx}$ & $\%$ & Fx & $\%$ & $\mathrm{Fx}$ & $\%$ \\
\hline Gender & & & & & & & & $p=0.61$ \\
\hline Female & 6 & 24.00 & 4 & 16.00 & 1 & 4.00 & 11 & 44.00 \\
\hline Male & 7 & 28.00 & 5 & 20.00 & 2 & 8.00 & 14 & 10.37 \\
\hline MIC Fluconazole (mg/L) & & & & & & & & $p=0.75$ \\
\hline Susceptible & 6 & 24.00 & 6 & 24.00 & 3 & 12.00 & 15 & 60.00 \\
\hline Doses Dependent susceptibility & 7 & 28.00 & 3 & 12.00 & 0 & 0.00 & 10 & 40.00 \\
\hline Resistance & 0 & 0.00 & 0 & 0.00 & 0 & 0.00 & 0 & 0.00 \\
\hline MIC Voriconazole (mg/L) & & & & & & & & $p=0.43$ \\
\hline Susceptible & 13 & 52.00 & 9 & 36.00 & 3 & 12.00 & 25 & 100.00 \\
\hline Doses Dependent susceptibility & 0 & 0.00 & 0 & 0.00 & 0 & 0.00 & 0 & 0.00 \\
\hline Resistance & 0 & 0.00 & 0 & 0.00 & 0 & 0.00 & 0 & 0.00 \\
\hline $\mathrm{CD}^{+} \mathrm{cel} / \mathrm{mm}^{3}$ (WHO Classification) & & & & & & & & $p=0.06$ \\
\hline$>500$ Not signnificant & 4 & 16.00 & 3 & 12.00 & 1 & 4.00 & 8 & 32.00 \\
\hline 350-499 Mild & 3 & 12.00 & 4 & 16.00 & 1 & 4.00 & 8 & 32.00 \\
\hline 200-349 Advanced & 1 & 4.00 & 1 & 4.00 & 0 & 0.00 & 2 & 8.00 \\
\hline$<200$ Severe & 3 & 12.00 & 0 & 0.00 & 0 & 0.00 & 3 & 12.00 \\
\hline Not Information* & $2 "$ & 8.00 & 1 & 4.00 & $1^{\mathrm{o}}$ & 4.00 & 4 & 16.00 \\
\hline Antiretroviral therapy (ART) & & & & & & & & $p=0.94$ \\
\hline 1-4 Drugss & 11 & 44.00 & 8 & 32.00 & 2 & 8.00 & 21 & 84.00 \\
\hline New patient No ART & $2 "$ & 8.00 & 1 & 4.00 & $1^{\mathrm{o}}$ & 4.00 & 4 & 16.00 \\
\hline Antimicrobial Therapy & & & & & & & & $p=0.47$ \\
\hline Antifungal & $2^{\wedge}$ & 8.00 & 0 & 0.00 & 0 & 0.00 & 2 & 8.00 \\
\hline Antibacterial & 3 & 12.00 & 2 & 8.00 & 1 & 4.00 & 6 & 24.00 \\
\hline Antiparasitic & 0 & 0.00 & 0 & 0.00 & 0 & 0.00 & 0 & 0.00 \\
\hline No Antimicrobial therapy & 8 & 32.00 & 7 & 28.00 & 2 & 8.00 & 17 & 68.00 \\
\hline
\end{tabular}

* New patients without information in the medical record at the sample collection day.

"New patient with tuberculosis

^ Both with doses dependent susceptibility to fluconazole

${ }^{\circ}$ New patient with neurocryptococosis

Vol. 60(4): 275 - 282, 2019 


\section{DISCUSSION}

The mean age of the patients was 36 years showing that HIV still is an infection among the young population as reported in other countries $(5,8-10)$. Within the 135 patients involved in this study, 90 were men and 45 were women, resulting in the ratio of two cases in men for every one case in women. Against what happens in some African countries with a female prevalence of $4.6 \%$ vs. $2.7 \%$ male prevalence and could be explained by the cultural, social, and economic vulnerability of women $(8,9,11)$. The last HIV database from Venezuela show that more than 100.000 men were seropositive and approx. 38.000 women, so even with the non-statistical significance observed in our study, data shows that the incidence of HIV in men remains high, with a slow increase in women and both are worrying (12).

Candida spp. oral colonization among HIV patients may predict the development of oropharyngeal candidiasis (OPC) as the most common opportunistic infection in these patients and the progression is faster and more severe as a progressive depletion of $\mathrm{CD}^{+} \mathrm{T}$ cells and/or failure to $\operatorname{ART}(3,5,8)$. No patient from this study had oropharyngeal candidiasis, however, $18.5 \%$ had Candida spp. colonization, being lower than the studies in HIV carriers in Argentina (72\%), Brazil (62\%), Cote d'Ívore (79.4\%), India (68\%) and Thailand (61\%) $(9,13-17)$. We found no difference in the $\mathrm{CD}^{+}$counts between patients colonized by Candida spp. as other studies had found (11). Suggesting, as other authors also observed, a protective effect of ART regimens against OPC $(1,5,18)$.

The patients without ART therapy one with complicated TBC and other with neurocryptococosis, both were considerate as severe immunodepression, using the WHO clinical staging as a guide for decision-making regardless of age or $\mathrm{CD}^{+}{ }^{+}$testing, particularly when the $\mathrm{CD} 4^{+}$count is not available $(5,18)$.
The susceptibility to an antifungal can be different between species and populations and the emergence of antifungal resistance made the identification of Candida spp. an essential to guide the therapeutic choice and clinical treatment $(8,19-22)$. We have found no resistance against $\mathrm{FCZ}$ or $\mathrm{VCZ}$, but $40 \%(n=10 / 25)$ of the species had DDS to FCZ: $12 \%(\mathrm{n}=3 / 25)$ C. albicans complex and $28 \%(\mathrm{n}=7 / 25)$ C. parapsilosis complex. Two of that seven were taking fluconazole, suggesting the exposure during ART provided a positive selection pressure for yeasts being less sensitive $(3,4,20,22)$, or could be because C. parapsilosis sensu extricto show more resistance to FCZ (23-26).

This study addresses the importance on identification and antifungal susceptibility as guide to proper treatment in any mycosis. We find a high proportion of non-albicans species, against most of the studies in HIV carriers where $C$. albicans complex remains as the most common species $(3,11,17)$. However, our data support Venezuelan's studies, where C. parapsilosis is the most frequent species isolated $(21,25,27-29)$. The epidemiology of Candida infections is changing: new species, better adapted virulence factors, further antifungal resistance and worse clinical presentations.

\section{ACKNOWLEDGMENT}

To all SAHUM HIV/AIDS program personnel and Ms. Zaida Bracho, UNEFM Mycology Lab.

\section{REFERENCES}

1. Nanteza M, Tusiime J, Kalyango J, Kasangaki A. Association between oral candidiasis and low $\mathrm{CD}^{+}{ }^{+}$count among HIV positive patients in Hoima Regional Referral Hospital. BMC Oral Health 2014;14:143. doi: 10.1186/1472-6831-14-143.

2. Li X, Lei L, Tan D, Jiang L, Zeng X, Dan H. Oropharyngeal Candida colonization in human immunodeficiency virus infected 
patients. APMIS 2013;121(5):375-402. doi: 10.1111/apm.12006.

3. Patil S, Majumdar B, Sarode SC, Sarode GS, Awan KH. Oropharyngeal candidiasis in HIV-infected patients - An update. Front Microbiol 2018; 15(9):980. doi: 10.3389/ fmicb.2018.00980.

4. Pfaller M. Antifungal drug resistance: mechanisms, epidemiology, and consequences for treatment. Am J Med 2012; 125(1Suppl):S3-13. doi: 10.1016/j.amjmed.2011.11.001.

5. UNAIDS. WHO case definitions of HIV for surveillance and revised clinical staging and immunological classification of HIV-related disease in adults and children. 2013;6-16.

6. Pfaller M, Andes D, Diekema D, EspinelIngroff $\mathbf{A}$, Sheehan $\mathbf{D}$. Wild-type MIC distributions, epidemiological cutoff values and species-specific clinical breakpoints for fluconazole and Candida: time for harmonization of CLSI and EUCAST broth microdilution methods. Drug Resist Update 2010; 13(6):180-195. doi: 10.1016/j. drup.2010.09.002.

7. National Committee for Clinical Laboratory Standards (NCCLS). Method for antifungal disk diffusion susceptibility testing of yeast. Approved guideline M44-A. 2004; 24:1-23.

8. Mushi MF, Bader OB, Taverne-Ghadwalb L, Biic Ch, Großb U, Mshanaa S. Oral candidiasis among African human immunodeficiency virus-infected individuals: 10 years of systematic review and meta-analysis from sub-Saharan Africa. J Oral Microbiol 2017;9(1):1317579. doi: 10.1080/20002297.2017.1317579.

9. Konaté A, Barro-Kiki PCM, Kassi KF, Angora $\mathrm{KE}$, Vanga-Bosson $\mathrm{H}$, Djohan $\mathrm{V}$, Bédia-Tanoh AV, Miézan AJS, Yavo W, Menan EIH. Oropharyngeal candidiasis prevalence among HIV-infected patients at the teaching hospital of Treichville. J Mycolog Med 2017;27(4):549-553. doi: 10.1016/j.mycmed.2017.08.005.

10. Dos Santos PM, MeArthur CP, Africa CW. Multi-drug resistant oral Candida species isolated from HIV-positive patients in South Africa and Cameroon. Diag Microbiol Infect Dis $2014 ; 79(2): 222-227$.
11. Nweze EI, Ogbonnaya UL. Oral Candida isolates among $\mathrm{HIV}$-infected subjects in Nigeria. J Microbiol Immunol Infect 2011;44: 172-177. doi: 10.1016/j.jmii.2011.01.028.

12. HIV InSite. University of California, San Francisco. Available on: http://hivinsite.ucsf.edu/global?page $=$ er05-ve$00 \&$ post $=19 \&$ cid $=$ VE. (Last date access December 31th 2015).

13. Theill L, Dudiuk C, Morano C, Gamarra S, Nardin ME, Méndez E, Garcia-Effron G. Prevalence and antifungal susceptibility of Candida albicans and its related species Candida dubliniensis and Candida africana isolated from vulvovaginal samples in a hospital of Argentina. Rev Argent Microbiol 2016;48(1):43-49. doi: 10.1016/j. ram.2015.10.003.

14. Terças AL, Marques SG, Moffa EB, Alves MB, de Azevedo MP, Siqueira WL, Monteiro CA. Antifungal drug susceptibility of Candida species isolated from HIVpositive patients recruited at a Public Hospital in São Luís, Maranhão, Brazil. Front Microbiol 2017;8:298. doi: 10.3389/ fmicb.2017.00298.

15. Junqueira $J$, Vilela $S$, Rossoni R, Barbosa J, Costa A, Rasteiro V, Suleiman J, Jorge O. Oral colonization by yeasts in HIV-positive patients in Brazil. Rev Inst Med Trop 2012;54(1):17-24. doi:10.1590/s0036-466 52012000100004.

16. Kaur R, Dhakad M, Goyal R, Bhalla P, Dewan R. Spectrum of opportunistic fungal infections in HIV/AIDS patients in tertiary care hospital in India. Can J Infect Dis Med Microbiol 2016: 2373424. doi: 10.1155/2016/2373424. Epub 2016 Jun 20.

17. Thanyasrisung $P$, Kesakomol $P$, Pipattanagovit $\mathrm{P}$, Youngnak-Piboonratanakit $\mathrm{P}$, Pitiphat W, Matangkasombut O. Oral Candida carriage and immune status in Thai human immunodeficiency virus-infected individuals. J Med Microbiol 2014;63(5):753759. doi: 10.1099/jmm.0.069773-0

18. Berberi A, Noujeim Z, Aoun G. Epidemiology of oropharyngeal candidiasis in human immunodeficiency virus/acquired immune deficiency syndrome patients and CD4+ Counts. J Int Oral Health 2015;7(3):20-23. PMID: 25878473; PMCID: PMC4385720. 
19. Enwuru CA, Ogunledun A, Idika N. Enwuru NV, Ogbonna F, Aniedobe M, Adeiga A. Fluconazole resistant opportunistic oropharyngeal candida and non-candida yeastlike isolates from HIV infected patients attending ARV clinics in Laǵos, Niǵeria. African Health Sciences 2008; 8(3):142-148.

20. Fothergill AW, Sutton DA, MeCarthy DI, Wiederhold NP. Impact of new antifungal breakpoints on antifungal resistance in Candida species. J Clin Microbiol 2014;52(3):994-997. doi: 10.1128/ JCM.03044-13.

21. Nucei M, Queiroz-Telles F, Alvarado-Matute T, Tiraboschi IN, Cortes J, Zurita J, Guzman-Blanco M, Santolaya M, Thompson L, Sifuentes-Osornio J, Echevarria J, Colombo A. Epidemiology of candidemia in Latin America: a laboratory-based survey. PLoS ONE 2013; 8(3): e59373. doi: 10.1371/journal.pone.0059373.

22. Osaigbovo I, Lofor P, Oladele R. Fluconazole resistance among oral Candida isolates from people living with HIV/AIDS in a Nigerian Tertiary Hospital. J Fungi (Basel). 2017;3(4):E69. doi: 10.3390/jof3040069.

23. Trofa D, Gácser A, Nosanchuk JD. Candida parapsilosis, an emerǵing fungal pathogen. Clin Microbiol Rev 2008;21(4):606625. doi: 10.1128/CMR.00013-08.

24. Saúl-García Y, Humbría-García L, Hernández-Valles R. Species distribution and antifungal susceptibility of Candida spp. causing superficial mycosis. Coro, Falcon state, Venezuela. Invest Clin 2015; 56(3): 276 283. PMID:26710542.
25. Moreno X, Reviakina V, Panizo MM, Ferrara G, García N, Alarcón V, Garcés MF, Dolande M. Identificación molecular y sensibilidad a los antifúngícos de aislamientos de sangre del complejo Candida parapsilosis en Venezuela. Rev Iberoam Micol 2017. http://dx.doi.org/10.1016/j. riam.2016.11.005.

26. Ngouana T, Krasteva D, Drakulovski P, Toghueo R, Kouanfack C, Ambe A, Reynes J, Delaporte E, Boyom F, Malli M, Bertout S. Investigation of minor species Candida africana, Candida stellatoidea and Candida dubliniensis in the Candida albicans complex among Yaoundé (Cameroon) HIV-infected patients. Mycoses. 2015; 58: 33-39. doi: $10.1111 /$ myc. 12266.

27. Saúl García Y, Hernández Valles R. Aislamiento de Candida spp. en ambiente y personal que labora en una unidad de cuidados intensivos. Rev Soc Ven Microbiol 2014; 34:27-32.

28. Perozo A, Calvo B, Mesa L, Pineda M. Susceptibilidad a fluconazol y voriconazol por el método de difusión, de cepas de Candi$d a$, aisladas de hemocultivos en Maracaibo, Venezuela. Kasmera 2011;38(2):114-122.

29. Calvo B, Mesa L, Perozo A, Pineda M, Beltrán-Luengo H. Cambios en la distribución de especies de Candida aisladas de hemocultivos, en pacientes del Servicio Autónomo Hospital Universitario de Maracaibo, Venezuela. Kasmera 2010;38(2):106-117. 